\title{
Urgency of Harmonization of Ministerial Regulations / Institutions in the Establishment of Legislation
}

\author{
Siti Masitah ${ }^{1}$, Faisal Santiago ${ }^{2}$ \\ Borobudur University, Indonesia \\ \{sitimasitah076@gmail.com¹, faisalsantiago@borobudur.ac.id²
}

\begin{abstract}
The establishment of legislation is the making of legislation that includes the stages of planning, drafting, discussing, ratifying or determining, and proposing. Harmonization is part of the drafting stage. Harmonization of Ministerial Regulation / Institution has a very important role in the establishment of legislation. By not entering the Regulation of ministers / institutions in the type and hierarchy of legislation based on Article 7 paragraph (1) of Law No. 12 of 2011 on the Establishment of Legislation, so that the harmonization is not coordinated by the Ministry of Law and Human Rights but by ministries / institutions. This raises the problem that there are still many Ministerial Regulations / Institutions contrary to higher laws and regulations, the principle of the establishment of good legislation, the principle of material content of legislation, court decisions, and equivalent legislation. Research using normative juridical legal research methods. The results of the study are expected to harmonize the urgency of the Regulation of the Minister / Institution in the establishment of legislation so as not to conflict with higher laws and regulations, the principle of the establishment of good legislation, the principle of material content of legislation, court decisions, and equivalent legislation.
\end{abstract}

Keywords: Harmonization; Regulation of the Minister / Institution; Establishment of Legislation

\section{Introduction}

Law No. 12 of 2011 on the Establishment of Legislation governs the procedure of the formation of legislation starting from the stage of planning, drafting, discussion, ratification or determination, legislation, and dissemination. The Law is an implementation of the order of Article 22A of the Constitution of the Republic of Indonesia year 1945 which states that "Further provisions on the procedure of the formation of the law shall be governed by law".

Law No. 12 of 2011 on the Establishment of Legislation is prepared based on the idea that the State of Indonesia is a country of law. Indonesia as a country of law then Indonesia makes the law as the norm in the country, where the law must be formed based on Pancasila, because it serves to create a system in society, then the law must be formed based on the ideology of the nation that became the ideals of the nation [1].

Indonesia as a country of law, all aspects of life in the field of society, nationality, and country including government must be based on the law in accordance with the national legal system. In the state order, religion and social ethics must be able to cooperate in integral unity 
in building an integrative Indonesian national legal system which means a legal system that is seen as relevant in the face of challenges and developments in the global world, where elements of the national legal system both religious legal system, customary legal system and positive legal system are interconnected and supportive in building a strong and dignified national legal system [2].

The national legal system is a law that applies in Indonesia with all its elements that support each other in order to anticipate and overcome problems arising in the life of children, state, and state based on Pancasila and the Constitution of the Republic of Indonesia year 1945. Pancasila is the source of all legal resources for the nation and the state of Indonesia. Therefore, all acts of power or power in the community must be in accordance with the laws and regulations derived from Pancasila. ReLaw Publik Indonesia in 1945 as a basic law is a general agreement (consensus) for citizens on basic norms (grundnorm) and basic rules (grundgesetze) in state and state life [1], [3].

Indonesia as a country of law, the state is obliged to carry out the development of national laws carried out in a planned, integrated, and sustainable in the national legal system that guarantees the protection of the rights and obligations of all Indonesians based on Pancasila and the Constitution of the Republic of Indonesia year 1945. Therefore, one of the priorities that must be done in the framework of national legal development is harmonization in the formation of legislation [4].

The establishment of legislation is a requirement in the framework of national legal development that can only be realized if supported by certain methods, standards, and standards that bind all authorized institutions to form legislation. The establishment of legislation is the creation of legislation that includes the stages of planning, drafting, discussion, ratification or determination, and announcement. The legislation will realize the laws and regulations in accordance with Pancasila and the 1945 State Constitution by putting forward a good concept in forming good laws and regulations, able to regulate, maintain and protect all people, nations and the state of Indonesia [5].

Harmonization is one part of the stage of drafting legislation. Harmonization is intended for (a) overlapping or conflicting laws and regulations (b) aligning conflicting laws and regulations proportionally to establish a system; (c) the process for realizing harmony, harmony, harmony, match and balance, (d) cooperation between various factors to reproduce awhole unity [6].

Harmonizing is intended not to conflict with higher laws and regulations based on the type and hierarchy of laws and regulations based on Article 7 paragraph (1) Types and hierarchies of legislation consisting of: a. The Constitution of the Republic of Indonesia year 1945; b. Provisions of the People's Consultative Assembly c. Law/Government Regulation Replacement Law; d. Government Regulations; e. Presidential Regulation; f. Provincial Regulation; and g. District/City Regulations. The legal force of the Laws and Regulations in accordance with the hierarchy as stipulated in Article 7 paragraph (2) of LawNo. 12 of 2011.

The hierarchical structure of legislation has consequences that a lower legislation should not be contrary to higher legislation. This is in line with the lex superior derogat inferiori legal principle that lower legislation should not be contrary to higher legislation. This is intended to create legal certainty in the legal system [7].

With the absence of Ministerial Regulation / Institution in the type and hierarchy of the legislation maka implications harmonizationand draft Regulation of the Minister / Institution is not coordinated by the Ministry of Law and HumanRights but by each ministry / institution,unlike theDraft Law derived from the President, Draft Government Regulation, Draft Presidential Regulation coordinated by the Ministry of Law and Human Rights as 
stipulated in Article 47 paragraph (3), Article 54 paragraph (2), Article 55 paragraph (2) Law Number 12 Year 2011.

However, the regulation of the Ministerial Regulation /Institution is stipulated in Article 8 paragraph (1) of Law No. 12 of 2011 stating that the type of legislation other than as referred to in Article 7 paragraph (1) includes regulations regulated by the People's Consultative Assembly, Dpr, Dewan Perwakilan Daerah, Supreme Court, Constitutional Court, Audit Board of Finance, Judicial Commission, Bank Indonesia, ministers, institutions, or commissions of the same level established by law or government by order of law, Provincial People's Representative Council, Governor, District/Municipal People's Representative Council, Regent/Mayor, Village Head or equivalent. The Regulation of the Minister /Institution is recognized for its existence and has a binding legal force as long as it is ordered by a higher law or formed based on authority as stipulated in Article 8 paragraph (2) of Law No. 12 of 2011.

Excluding ministerial/institutional regulations in the hierarchy of legislation as opposed to Hans Kelsen's theoretical understanding of pure legal theory in his book "General Theory of Law and State" examines a legal norm in which it is multilayered and tiered, where the legal norm is based on a higher legal norm while the higher legal norm applies, it is sourced to a higher legal norm up to the highest legal norm again, to a high legal norm called the basic norm and is hypothetical and fictitious (grundnorm) [8].

The problems arising from excluding the Ministerial/Institution Regulation in the hierarchy of implied laws and regulations are still many Ministerial/Institution Regulations that are contrary to higher legislation, the principle of the establishment of good legislation, the material principle of the content of legislation, court rulings, and equivalent legislation. On the issue so that it is necessary to research the urgency of harmonizing the Regulation of ministers / institutions in the formation of legislation.

\section{Research Methods}

The method used in the form of normative juridical research using the statute approach is used in researching, reviewing, studying, understanding the laws and regulations governing the urgency of harmonizing the Ministerial/Institutional Regulations in the Formation of Legislation.

\section{Result and Discussion}

\subsection{Procedure for Harmonizing the Draft Regulation of the Minister / Institution in the Formation of Legislation}

Government Regulation No. 59 of 2015 concerning the Participation of The Designer of Legislation in the Establishment of Legislation and Its Development. The Government Regulation is a regulation on the implementation of the provisions of Article 98 paragraph (1) of Law No. 12 of 2011 which stipulates that "The provisions on the participation and development of the Drafter of the Legislation as referred to in paragraph (1) shall be governed by a Government Regulation".

In this Government Regulation one of the articles of Article 3 paragraph (2) of Government Regulation No. 59 of 2015 stipulates that "In carrying out the task of preparing, 
processing, and formulating the Draft Legislation and other legal instruments, the Designer must harmonise". Based on the provisions, the designer of legislation through the Development Agency, namely the Ministry of Law and Human Rights, stipulates Regulation of the Minister of Law and Human Rights No. 23 of 2018 concerning The Prohibition of Draft Ministerial Regulations, Draft Regulations of Non-Ministerial Government Institutions, or Draft Regulations of Nonstruktural Institutions by the Draft Legislation.

With the enactment of the ministerial regulation so that the draft Regulation of the Minister / Institution must be harmonized by the designer of the legislation. The initiating agency submits an application for the harmonization of the Draft Regulation of the Minister /Institution in writing to the Minister of Law and Human Rights through echelon I units within the Ministry of Law and Human Rights, namely the Director General of Legislation as the Supervisor of the draft legislation.

In the meeting of the prohibition of the draft Regulation of the Minister / Institution invites the initiating agencies and government agencies or related agencies related to the substance of the Regulation of the Minister / Institution to be harmonized. If you need the expertise of experts, you can invite expert speakers to establish legislation.

The meeting on the harmonization of the draft Ministerial/Institutional Regulation is led by the drafter of the legislation. Representatives of ministers or leaders of the initiating institutions are given the opportunity to present the points of thought behind the formation of the Draft Regulation of the Minister / Institution and the outline of the content material. Furthermore, representatives of the relevant agencies are given the opportunity to submit responses, opinions, or proposed changes, either directly or in writing.

The responses, opinions, or proposed changes presented in the harmonization meeting generally concern content material related to the scope of the duties or authorities of the agencies represented. Furthermore, the various responses were discussed in depth. Often the discussion goes on rather long because of the attraction of interinstansi interests. Long discussions generally concern authority, institutional, financial management, procedural arrangements, determination of rights and obligations and sanctions. If a crucial issue that becomes the subject matter cannot be found a solution or cannot be agreed upon, then the Meeting is chaired by the Primary High Leadership Officer or Administrator within the Directorate General of Legislation in the framework of the function of coaching and supervision.

The Primary High Leadership Officer or Administrator submits the results of the harmonizing of the draft Ministerial/Institutional Regulation to the Director General of Legislation to obtain a decision. The draft Regulation of the Minister / Institution that has been harmonized by the draft legislation through the Director General of Legislation is submitted back to the Initiator by attaching a certificate has been harmonized draft Regulation of the Minister / Institution.

\subsection{The Urgency of Harmonizing the Ministerial/Institution Regulation in the Formation of Legislation}

The harmonization of the Ministerial/Institution Regulation in the formation of legislation includes 2 (two) aspects, namely aligning aspects related to substance and aspects related to the technique of drafting legislation.

\section{a) Aspects Related to the Substance of the Legislation}


1. Monization of the substance of the draft Regulation of ministers / institutions with Pancasila. Pancasila is the source of all sources of state law as stipulated in Article 2 of Law No. 12 of 2011. That is, the placement of Pancasila as the source of all sources of state law. Pancasila became the source of all legal sources that became the basic norm of the Indonesian nation in shaping the laws and regulations. Each draft Regulation of the Minister /Institution must be substantially implemented in the content of legislation with the values of godliness, humanity, unity, populism, and social justice with the following explanations: The values of Pancasila are accommodated with the first precept of "The One True God", should be the basis for political and legal policies in legislation based on religious morals and beliefs; b. the second precept, "Just and Civilized Humanity" becomes the basis of political and legal policies in legislation that respects and protects nondiscrimination human rights; c. the third syllabus, "Persatuan Indonesia" becomes the basis of legal political policy in the legislation to unite all elements of the nation with their respective primordial ties; $d$. the fourth syllabus, "Populism Led by Wisdom in Consultative/Representative, becomes the basis of political and legal policy in legislation that puts power under the rule of the people (democracy); and e. Social Justice for All Indonesians, becomes the basis of political and legal policies in the laws and regulations that in public life based on social justice and not arbitrary towards others [9].

2. The substance of the draft Ministerial/Institutional Regulation with the Constitution of the Republic of Indonesia of 1945. The Constitution of the Republic of Indonesia year 1945 is the basic law in the Laws and Regulations as stipulated in Article 3 of Law No. 12 of 2011. The Constitution of the Republic of Indonesia year 1945 which contains the basic law of the state is a legal source for the formation of legislation under the Constitution, so that the material content of certain articles that are used as the basis for its formation and articles related to the substance to be further regulated, must also be in line with the principles of the state of law and the state of democracy, both in the economic, political, social, and cultural fields.

3. Harmonizing the draft Regulation of the Minister / Institution with the principle of formation and material basis of the content of legislation. The principle of legislation is divided into 3 (three) groups, namely:

a. The principle of the establishment of good legislation. The explanation of the principles in Article 5 of Law No. 12 of 2011 is as follows:

1. The "principle of clarity of purpose" is that any Statutory Formation must have a clear goal to be achieved.

2. "institutional principle or proper forming officer" is that any type of Legislation must be made by state institutions or authorized Legislators. Such legislation may be annulled or null and void if made by a state agency or an unauthorized official.

3. "the principle of conformity between types, hierarchies, and material content" is that in the Formation of Legislation must really pay attention to the appropriate content material in accordance with the type and hierarchy of legislation.

4. "enforceable principle" is that any Formation of Legislation must take into account the effectiveness of such legislation in society, both philosophically, sociologically, and juridically.

5. The "principle of usability and usefulness" is that every Regulation of The Law is made because it is really needed and useful in regulating the lives of society, nation, and state. 
6. The "principle of clarity of formulation" is that each Legislation must meet the technical requirements of drafting legislation, systematics, choice of words or terms, as well as a clear and easy-to-understand legal language so as not to cause a variety of interpretations in its implementation.

7. "principle of openness" is that in the Establishment of legislation ranging from planning, drafting, discussion, ratification or determination, and invitation is transparent and open. Thus, all levels of society have the widest opportunity to provide input in the Establishment of Legislation

b. The material principle of the content of the legislation. The explanation of the principles in Article 6 paragraph (1) of Law No. 12 of 2011 is as follows:

1. "the principle of appearity" is that any Statutory Content Material must serve to provide protection to create community tranquility;

2. The "principle of humanity" is that any Material Content of the Laws and Regulations shall reflect the protection and respect of human rights and the dignity and dignity of every Indonesian citizen and resident proportionally,

3. "national principle" means that any Material Content of the Laws and Regulations shall reflect the compound nature and character of the Indonesian nation while maintaining the principles of the Unitary State of the Republic of Indonesia,

4. "family principle" is that any Statutory Content Material must reflect deliberations to reach consensus in every decision making,

5. "the principle of aerospace" is that every Material Content of the Laws and Regulations always pay attention to the interests of all regions of Indonesia and the Content Material of laws and regulations made in the region is part of the national legal system based on Pancasila and the Constitution of the Republic of Indonesia year 1945,

6. "the principle of bhinneka tunggal ika" is that the Content Material of the Legislation must pay attention to the diversity of population, religion, ethnicity and class, special conditions of the region and culture in the life of society, nation, and state, and

7. The "principle of fairness" is that any Statutory Content Material shall reflect justice proportionately for every citizen,

8. "the principle of equality of position in law and government" is that any Material Content of the Laws and Regulations shall not contain anything that is distinguishable based on background, among others, religion, ethnicity, race, class, gender, or social status,

9. "the principle of order and legal certainty" is that any Material Content of legislation must be able to realize order in the community through the guarantee of legal certainty,

10. The "principle of balance, harmony, and harmony" is that any Material Content of the Laws and Regulations shall reflect the balance, harmony, and harmony, between the interests of individuals, communities and the interests of the nation and state.

c. Other principles in accordance with the field of legislation in question. The explanation of the principles in Article 6 paragraph (2) of Law No. 12 of 2011 is as follows: 
1. In Criminal Law, for example, the principle of legality, the principle of no penalty without wrongdoing, the principle of inmate construction, and the principle of presumption of innocence;

2. In Civil Law, for example, in treaty law, among other things, the principle of agreement, freedom of contract, and good faith.

4. Harmonizing the substance of the draft Ministerial Regulation / Institution with higher legislation and equivalent legislation. The harmonization of the draft Regulation of the Minister / Institution in the formation of legislation should not be contrary to higher legislation in accordance with the type and hierarchy of legislation based on the provisions of Article 7 of Law No. 12 of 2011 that the type and hierarchy of legislation. In terms of lex superiori delogat legi inferiori principle, which means higher legislation overrides lower legislation. So in the formation of legislation must ensure that the content material stipulated in the legislation is not contrary to the above laws and regulations. The legislator must draft a statutory regulation in accordance with the articles in the higher legislation which is the article that is the basis of the formation of the legislation. This is called vertical harmonization of legislation, namely harmonization of legislation with other laws and regulations in the hierarchy of higher legislation. The significance of vertical harmonization of this legislation is that in the Indonesian legal system such legislation can be tested by the power of the judiciary (material test rights). Article 24 A paragraph (1) of the Constitution-1945, states that the Supreme Court is authorized to adjudicate at the cassation level, test the laws and regulations under the law, and have other authority granted by law. Furthermore Article 11 paragraph (2) Letter b of Law No. 4 of 2004 concerning the Power of Justice, states the Supreme Court has the authority: to test the laws and regulations under the law against the law. With these rules, a regulation can be Judicial Review to the Supreme Court if the content material there is a provision that is contrary to the provisions in the legislation that is hierarchically higher. The prohibition of the draft Regulation of the Minister / Institution in the formation of legislation should not be contrary to the equivalent legislation, namely legislation with other laws and regulations in the same hierarchy. Horizontal harmonization departs from the principle of lex posterior delogat legi priori which means a new legislation overrides the old legislation and the principle of lex specialist delogat legi generalis which means a special legislation to override the general legislation. Horizontal harmonization of legislation based on these two principles is very important in the preparation of a statutory regulation because in essence a statutory regulation is a form of regulation that is cross-sectoral and cannot stand on its own. In the legislation there are various sectors and areas of law that are different but interconnected and connected to each other so that a comprehensive, round and complete arrangement is needed. The legislator in this case needs to coordinate with the relevant agencies with the substance to be regulated in the legislation. If the horizontal harmoization process of this legislation fails to be implemented, there will be overlap between sectors and legal fields in a country's legal system. This condition will have a massive impact because it can create legal uncertainty and ambiguity in the application of the legislation that ultimately the purpose of the law to serve the purpose of the state is to create the welfare of the people. Horizontal harmonization of the legislation is carried out based on the principle of Lex Posterior Delogat Legi Priori against a regulation of the company- legislation that is in the same hierarchy and equivalent and in practice stipulated in the closing provisions of a legislation. 
5. Harmonizing the substance of the draft Ministerial/Institution Regulation with the decision of the Constitutional Court and the Supreme Court. In harmonizing the draft Regulation of the Minister /Institution must also pay attention to the test verdict against the Law/Government Regulation Replacement Law decided by the Constitutional Court and the test decision of government regulations, presidential regulations decided by the Supreme Court because the decision of the Constitutional Court and the Supreme Court is final and binding is an interpretation that is legally formally guaranteed by the constitution as an official interpretation. The Law/Government Regulation Replacement Law, Government Regulation, Presidential Regulation with the articles and spirit of the Constitution of the Republic of Indonesia year 1945 as stated in the opening, can be tested its validity by the Constitutional Court and the Supreme Court.

\section{b) Technical Aspects of Drafting Legislation}

The technique of drafting legislation is a method based on special expertise in order to arrange written regulations that contain generally binding legal norms and are established or established by state agencies or authorized officials through the procedures stipulated in the laws and regulations. In harmonizing the draft Regulation of the Minister / Institution should be aligned technically the preparation of legislation contained in annex II of Law No. 12 of 2011 on the Establishment of Legislation, both concerning the framework of legislation, special matters, language, and the form of legislation.

\subsection{How to Harmonize the Draft Regulation of the Minister / Institution in the Formation of Legislation}

Harmonizing is done in the following ways:

a. Make sure that the draft Regulation of the Minister / Institution lists the philosophical values of Pancasila and the draft articles of legislation in question does not conflict with these values.

b. Ensure that the draft Regulation of the Minister/Institution is in accordance with the principles of state administration according to the 1945 Constitution.

c. Use legal terms or legal definitions consistently.

d. Carefully examine whether the material content of the draft Ministerial Regulation / Institution has been compatible / in accordance with the higher legislation or equivalent.

e. Ensure that the principles of the establishment of good legislation, material principles of content, and other principles related to the legal field stipulated in the draft law, have been well accommodated in the draft Ministerial/InstitutionRegulations.

f. Ensure that the technical guidelines for drafting legislation have been adhered to consistently. Make sure that the language used in formulating the norms in the draft Ministerial/Institution Regulation is in accordance with the rules of the Indonesian language that is good and correct and uses the right, clear and definite word choices [10].

\subsection{The Purpose of Harmonizing the Regulation of Ministers/Institutions in the Formation of Legislation}

Ministerial/Institutional Regulations are an integral part of the national legal system. Regulation of the Minister / Institution is one type of legislation as a system or sub system of a 
larger system must be interconnected, interdependent, and is a complete roundness. This is important, considering that legislation is a subsystem of a legal system and to ensure that a statutory regulation can be compatible into the legal system so as not to cause difficulties in the application of the provisions of the legislation.

Ministerial/Institution regulations cannot be tested (judicial review or constitutional review) either materially or formally. The Supreme Court is authorized to test the laws and regulations under the Law against the Law as stipulated in Article 24A paragraph (1) of the Constitution of the Republic of Indonesia of 1945. Testing of Ministerial/Institutional Regulations can be conducted in the Supreme Court. Therefore, the function of harmonizing the Ministerial Regulation / Institution is very strategic as a preventive effort to prevent the testing of ministerial regulations / institutions by competent judicial powers. The decision of the judicial power may state that a material content of articles, paragraphs, and/or parts of the Ministerial/Institutional Regulation has no binding legal force or has no broad juridical and social impact. Therefore, harmonizing needs to be done carefully.

Ensuring the process of establishing a Regulation of ministers / institutions is carried out in a principled manner for legal certainty. The process of forming legislation needs to be done in a strict manner in order to form good legislation that meets various requirements related to the system, principles, procedures of delivery and discussion, technical preparation and enforcement by opening access to the public to participate. Regulation of the Minister / Institution as a written law that is very important in the national legal system and binding on the public must contain legal certainty that any Material Content of legislation must be able to realize order in the community through the guarantee of legal certainty, so that the consequences of certain actions that are appropriate or contrary to the law can be predicted. Thus, the Regulation of ministers / institutions can be an important means to maintain a synergistic relationship between citizens, and between citizens and the government to realize the common goal dynamically, orderly, and orderly.

\section{Conclusions and Suggestions}

\subsection{Conclusion}

Procedure for Harmonizing the draft Regulation of the Minister / Institution in the formation of legislation. The procedure of harmonizing the draft Regulation of the Minister / Institution in accordance with the Regulation of the Minister of Law and Human Rights No. 23 of 2018 concerning The Harmonization of the Draft Ministerial Regulation, Draft Regulation of Non-Ministerial Government Institutions, or Draft Regulation of Nonstruktural Institutions by the Draft Legislation.

The urgency of harmonizing the draft Regulation/Minister in essence aligns the content of the Regulation/Minister by:

a. Aspects related to the substance of the legislation include the values contained in Pancasila, the Constitution of the Republic of Indonesia year 1945, the principle of formation and material principles of the content of legislation, other principles in accordance with the field of law in question, higher legislation, equivalent legislation and court decisions of the Constitutional Court, and supreme court decisions.

b. Aspects of the technical preparation of legislation include the framework of legislation, special matters, the variety of language of legislation, and the form of draft legislation. 
The purpose of harmonizing the draft Regulation / Minister has a very strategic function in order to realize the national legal system based on Pancasila and the Constitution of the Republic of Indonesia year 1945, Regulation of the Minister / Institution can not be tested (judicial review or constitutional review) both materially and formally, ensuring the process of forming a Regulation of the Minister / Institution is carried out in a principle for legal certainty.

\subsection{Suggestions}

The prohibition of the draft Regulation of the Minister / Institution carried out by the designer of the legislation should be strengthened again through the Pembina Agency functional position of the drafter of legislation, namely the Ministry of Law and Human Rights by proposing a Regulation of the Minister / Institution in the type and hirerarki legislation as stipulated in Article 7 paragraph (1) Law No. 12/2011 on the Establishment of Legislation by revising Law No. 15 of 2011 concerning Amendments to Law No. 12 of 2011 concerning the Establishment of Legislation.

\section{References}

[1] A. Ismayawati, "Pancasila sebagai Dasar Pembangunan Hukum Di Indonesia," YUDISIA J. Pemikir. Huk. dan Huk. Islam, vol. 8, no. 1, p. 53, 2018, doi: 10.21043/yudisia.v8i1.3231.

[2] N. Umar, "Konsep Hukum Modern: Suatu Perspektif Keindonesiaan, Integrasi Sistem Hukum Agama Dan Sistem Hukum Nasional," Walisongo J. Penelit. Sos. Keagamaan, vol. 22, no. 1, p. 157, 2014, doi: 10.21580/ws.2014.22.1.263.

[3] D. Roza, U. Ekasakti, S. Tinggi, and I. Hukum, "Perundang-Undangan Untuk Mewujudkan Indonesia," no. September, pp. 131-144, 2019, doi: 10.3376/jch.v5i1.185.

[4] Soegiyono, "Pentingnya Harmonisasi dalam Pembentukan Peraturan PerundangUndangan," Kaji. Kebijak. dan Huk. Kedirgant., pp. 1-21, 2020, doi: 10.30536/9786023181339.1.

[5] F. Irawan Febriansyah, "Konsep Pembentukan Peraturan Perundang-Undangan Di Indonesia," Perspektif, vol. 21, no. 3, pp. 220-229, 2016, [Online]. Available: http://jurnal-perspektif.org/index.php/perspektif/article/view/586.

[6] Dewi Gunawati, "Urgensitas Harmonisasi Hukum Perlindungan dan Pengelolaan Hutan dalam Mitigasi Perubahan Iklim Global melalui Program,” vol. 4, no. 1, pp. 143-172, 2015, [Online]. Available: https://jurnal.uns.ac.id/yustisia/article/view/8630.

[7] P. Y. Partisipatif and D. A. N. Berkeadilan, "Jurnal Hukum," vol. 35, no. 2, pp. 59-72, 2019.

[8] T. Pane, "Kemungkinan Peraturan Perundangan-Undangan Di Bawah Undang-Undang Sebagai Obyek Pengujian Mahkamah Konstitusi," J. Huk. Pembang., vol. 41, no. 3, p. 398, 2011, doi: 10.21143/jhp.vol41.no3.253.

[9] S. Suryani, "Nilai Moralitas dalam Pembentukan Peraturan Perundang-Undangan," Pena Justisia Media Komun. dan Kaji. Huk., vol. 19, no. 2, pp. 117-130, 2020, doi: 10.31941/pj.v19i2.1147.

[10] I. T. Nur, "Singkronisasi dan Harmonisasi Peraturan Perundang - Undangan," pp. 158174, 2014. 
